\title{
Quality of Employment: Strategies and Interpretations of Spanish Employers and Trade Unions
}

\author{
María Arnal, Carlos Prieto \\ Universidad Complutense de Madrid \\ m.arnal@cps.ucm.es; cprieto@cps.ucm.es \\ María Caprile \\ CIREM Barcelona \\ maria.caprile@cirem.org
}

\begin{abstract}
This article examines the different discourses of trade unions and employers on quality of employment in Spain. The study takes a qualitative approach, using discussion groups to obtain discursive information about the meanings of quality, assessments and the different strategies employed by social agents. Trade unions use the 'quality discourse' as a reason to examine and reconstruct their current role, extending their main concerns and paradigms from those which defend workers' interests to those which consolidate their criticism of a reprehensible Spanish employer class. Employers' discourse, on the other hand, is aimed at highlighting the market's productive purpose, and sustaining their privileged position in labour management, whilst disassociating and distancing themselves from the employment decisions they make.
\end{abstract}

Keywords: Quality of employment, precarious job, decent work, trade unions, employers, Spain.

Resumen: Este artículo explora los diferentes discursos de los sindicatos y los empresarios sobre la calidad de empleo en España. El estudio adopta una aproximación cualitativa y utiliza grupos de discusión para obtener información discursiva sobre los significados de la calidad, valoraciones y estrategias empleadas por los agentes sociales. Los sindicatos utilizan el 'discurso de calidad' para examinar y reconstruir su papel en la actualidad ampliado sus principales preocupaciones y paradigmas 
para incluir no sólo la defensa de los intereses de los trabajadores, sino también la crítica de una reprobable clase empresarial española. El discurso de los empresarios, en cambio, pretende destacar la finalidad productiva del mercado y mantener su lugar de privilegio en la gestión del trabajo, pero desvinculándose y distanciándose de las decisiones que toman sobre el empleo.

Palabras clave: Calidad del empleo, trabajo precario, trabajo decente, sindicatos, empresarios, España. 


\section{Introduction}

Although numerous references have been made to quality of employment ${ }^{1}$ by very diverse social agents in recent years, qualitative approaches to studying the issue are much less common. This study of the discourse on the quality of employment in Spain is part of and benefits from research with a far broader scope (using quantitative and qualitative methodologies) on the subject in question. ${ }^{2}$ This study aims to reveal the opinions of the social agents involved in quality of employment and to address the discursive use these agents make of quality to refer to the current job market situation in Spain. ${ }^{3}$

This study uses a qualitative approach consisting of discussion groups (not focus groups) (Gutiérrez, 2008; Canales, 2006; Callejo, 2001) to obtain discursive information, which was then analysed from a sociological perspective (Conde, 2009; Alonso, 1998). Two groups were formed with very specific characteristics and requirements as far as the design and the choice of their members were concerned. The study design contemplates only two social agents, employers and trade unions, as their central importance today and in the past mean that they can provide opposing and more diverse opinions on the subject of employment quality in Spain. The complication lies in the fact that our discussion groups consisted of authorised representatives of these two groups of social agents and in that the members did not hold especially preferential or important institutional positions which could excessively politicise (rationalise) the topic of debate. The groups were formed in the third quarter of 2008, at a time when the worldwide economic recession, which began at the end of 2007, was still biting and, therefore, its influence on the Spanish job market situation and on the discourses arising in the discussion groups must be taken into consideration. ${ }^{4}$

1 For instance, Barbier, J.C. and Schylla, N.S. (2004), Gallie, D. (2007), Clark, A.E. (2005), Green, F. (2006), Kalleberg, A.L., Reskin, B.F. and Hudson, K (2000), Rusell, J.P. (Dir.) (2000), Sengupta, S. et alii (2009), Davoine, L., Erhel, C. and Guergoat-Lariviere, M. (2008).

2 An expanded version of this article has been accepted for publication in the International Journal of Society Systems Science. This article uses part of the research results on the quality of employment in Spain (Prieto, C. et alii, 2009).

3 The 2005 Survey on Income and Living Conditions (conducted before the current recession which began in 2008) found $28 \%$ unstable and badly paid employment in Spain compared to $14-17 \%$ in other countries in Europe (Prieto et alii, 2009). These data have worsened with the current crisis. The unemployment and temporary work rate in Spain now stand at $24.63 \%$ (2012) and $23.6 \%$ in the second quarter respectively, twice the European rates.

4 For a theoretical and methodological explanation see Arnal, M., Prieto, C. and Caprile, M. (In press). 


\section{The discourse of spanish employers and trade unions on the quality of employment}

In this section we first present the varying significance these groups attach to quality of employment, and then offer an analysis of the differing comparative assessments by employers and trade unions.

\subsection{The meaning of quality of employment}

Quality is understood in the groups as an assessment or judgement which is made about something (a product). The quality of this something (a multiplicity of subjects: trabajo de calidad, salario de calidad, seguridad en el trabajo de calidad, formación de calidad, etc.) is rated good or bad, and all the gradients in between. Quality is also understood as something positive and desirable (in itself), whilst bad quality does not have any or lacks quality. Quality, therefore, is an attribute resulting from positively assessing and rating an already existing product. The what, how and why are issues the groups discuss and elaborate on based on their respective discursive positions. The groups divide the quality of employment into four categories: quality as certification, as control, as testing and as sampling.

As far as certification is concerned, quality is understood as the validation of the product depending on the presence or absence of certain skills or attributes. These are specific aspects which can be established objectively: for example, a worker's level of education, salary, type of contract, etc. The purpose of the judgement is to verify the presence or the absence of skills, stating whether the quality of the item to be recorded is good or bad as a result. In addition, another essential task of this certification is to highlight that the evaluator is competent in the matter in question.

Quality as control stems from understanding quality as the supervision involved in the process or development of the product. Whilst employers place more emphasis on certification, trade unions are more inclined towards control, in which they understand that the quality of employment is not limited nor does it only apply to the attributes of the product, but rather to everything involved in qualifying it. This is why control especially refers to the scope of particular conditions or circumstances which make it possible to judge a certain quality of employment. In this respect, quality allows us to discover the formation processes, deficiencies or errors, difficulties or problems of the evaluated product. As if it were a front door, the product is a connection with aspects or circumstances which give rise to or can generate a certain quality of employment. 
Quality is often also understood as a test or experiment which seeks certain results by which employment can be judged. In this case, the product is compared (tested) in diverse contexts or circumstances to discover its quality. This use is in evidence when the quality of employment is viewed in terms of wages that cannot be lived on or training that does not match the tasks to be performed, etc.

Lastly, quality can be understood as sampling, based on the use of quality as the experience in which the product forms part of particular or subjective appreciations. In this case, quality is a non-transferable and personal part of a direct experience with the product. The quality of employment becomes a question of tastes which depend on individual circumstances and experiences. For example, the quality attributed to the same job or working conditions will depend on the type of worker or employer, their specific personal situations, etc.

Taking these four areas into account, the quality of employment lies either in the product of employment (set of properties or attributes of employment: salary amount, level of security, type of contract, etc.), or in prior socio-economic relationships entered into by the agents who intervene in creating the quality of the employment (compliance with collective bargaining, asserting rights, complying with rulings, union or employer concessions, etc.). Both ways of addressing quality also refer to the economic and legal, and the social and cultural spheres. In other words, quality of employment refers to business and to everything that directly or indirectly surrounds or interacts with it.

Figure 1: Four areas of quality in the job market

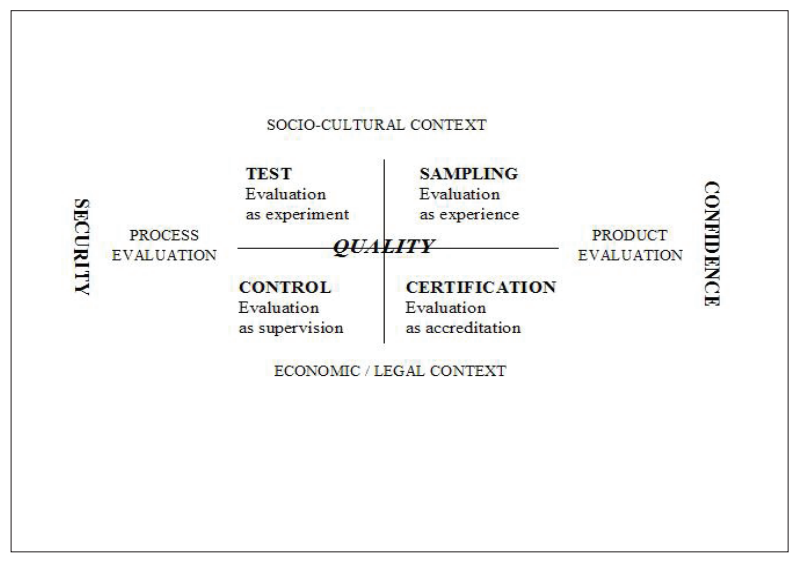

As shown in Figure 1, the organisation of the four areas of quality in employment demonstrates that understanding this quality as control means focusing interest on the associations that economic and social agents draw among 
issues related mainly to the job market, the country's economic situation, taxes, the operation of the various organisations, etc. In contrast, quality understood as certification focuses interest expressly on outcomes or products derived from a company's economic activities, and especially labour activities (productivity, type of contracts, salaries, training, security, etc.).

In the horizontal part at the top of the figure, on the other hand, quality refers to situations directly or indirectly related to work and the economy. Personal or family experiences, immigration, housing, health and consumption are issues which the groups take into account to refer to product quality, or the associations made between these products and other social and cultural factors, for example, a man's low salary is linked to guilt and laziness, and a woman's low salary to acceptance of social standardisation: 'A man does not even entertain the idea of having a job earning $€ 500$. Generally, the first thought that goes through your head is that he's lazy. For a woman, $€ 500$ is perfectly normal' (Union Group, UG).

In some cases, quality is seen as sampling, i.e. specific aspects of work are judged and rated on the basis of other similar situations in which the workers or employers have had better or worse results, for example, changing jobs, or the employer introducing immigrant labour. In others, these aspects of the work can be tested for coherence or suitability with other areas, such as consumption, health, education, family, etc.

The two groups refer to quality of employment in different ways and the value they attribute to it differs. Quality takes on the values of responsibility and unmasking in control and testing - the objective is to uncover the trick, deceit and/or lie. In contrast, quality espouses the values of management and organisation in certification and sampling, and demonstrates the part which can be disposed of, as it is not suitable or of interest in the quest to attain quality. Nevertheless, in both of these views (responsibility/management), the quality of employment in Spain was considered negatively by both the union group and the employer group, although for the former, poor quality is historic and alarming in the current situation, whilst for the latter, it depends on the country's economic and social circumstances, and the lack of foresight and reforms in the Spanish job market.

\subsection{Differing comparative assessments by employers and trade unions}

The groups rated the quality of employment differently based on three factors: contents, agents, and contexts. 
Assessments of the contents or product of quality of employment

With reference to the contents or product that can be identified or connected with the quality of employment, neither group has a clear referent. Sometimes it is defined by the type of work, other times by the training required, the hours, salary, etc. They assume, however, that the contents of the product are clearly deficient and have to be improved. This involves recognising the inconsistency and weakness of the product by which quality of employment is judged.

This inconsistency manifested itself equally in both groups, although in the union sample it was the consequence of understanding the product diachronically, as transformations that are continuously taking place in the sphere of employment and society. On the one hand, the contents have transformed over time with improvements and setbacks, and even the very notion of quality has changed. Aspects once considered a part of quality employment have later been considered insufficient or as indicative of poor quality as a result of the transformations that have occurred. Furthermore, the quality of the contents seems to have improved in some aspects (appropriate weekly hours, training, work and family life balance, etc.), while deteriorating in others (all these improvements in exchange for low salaries), creating the sensation of immobilisation and of an unfinished or halffinished product: "The years have gone by and now they tell us they're not going to give us any more pay rises because there's a recession as well, and we've noticed that they haven't improved at all in any of these aspects' (UG).

Whilst for the trade union group the inconsistency of the quality employment product cuts across time, for the employer group, the product lacks consistency due to apparently synchronous reasons related to the pressure of competing in an increasingly competitive job market. Consequently, the metaphor this group used to refer to what the employer looks for in the market as a 'quality employment' product is a backpack or container which every worker takes with him, and which he or she must go about filling to obtain quality employment: 'People need to be made aware of the fact that they have to improve, i.e. the backpack effect, I mean I have to improve my curriculum vitae' (Employer Group, EG).

Training, a good attitude towards work, initiative, and responsibility are all contents that might be in the container, but they automatically mean quality of employment. With regard to quality, employers are not concerned about the contents workers should have in their backpacks. In this group's words, quality employment requires workers' aptitudes and attitudes, but which ones and how many are necessary depend on the work the worker wishes to perform, thus establishing a proportional and fair correspondence between what the worker's backpack contains and what he or she is offered by employers or the market. The 
fewer contents there are, the more employment quality decreases, and vice versa, which is why there are differing qualities of employment for the performance of the same job.

With regard to the weakening of the product in relation to the quality of employment, the groups seem to refer to a process of loss of value and contents for various reasons, derived from circulating them or putting them into practice. In the case of the union group, this deterioration occurs when the quality which all jobs should have is taken advantage of for financial reasons by the agents intervening in their production. In other words, for any product, the contents that the quality of employment may include are decimated and reduced to a minimum until quality is totally absent. Consequently, the union group understands that the judgement of the quality of employment goes beyond the business sectors or particular contents of each company or employment relationship. The result of including this quality in the job market means that the same product goes on to form part of monetary gains. This is how the subcontracting phenomenon is understood. Given that the quality of employment has a value, and that this value translates into money, subcontracting boosts the accumulated profits to the detriment and degradation of the quality of employment offered.

Although this weakening of the product is obvious for the employer group, they refer to it very differently than the union group does. For the employers, the product initially has assumed quality which can be improved upon (but not lost) to maintain the level of competition in the market. These improvements refer to both the financial side (investments in training) and the institutional or administrative side (grants and incentives). As a result, improving the quality of employment is difficult because not enough information, and/or rigid administrative and management formalities prevent small and medium-sized business owners from considering certain demands and resources (grants for training, financial incentives, technical advice, etc.). Misinformation, the fears of Spanish small and medium-sized enterprise owners, as well as difficulties with managing employment improvements are factors which lead to only large companies having sufficient capacity and resources to take advantage of and incorporate the benefits of higher quality.

In short, the employer discourse recognises that incorporating quality into employment is already linked with workers and their 'backpacks' and, in the worst-case scenario, employers should not prevent their possible improvement, but should instead promote constant professional development for increased competitiveness. This is an apparently progressive view (open to change) of the product which the union group understands in conservative terms (maintaining 
the status quo) so that the quality of employment, considered as an absolute value, does not lose part of its unity. Whilst for the employers improvements are positive, since they add new and more contents making it possible to value the quality of employment, for the trade unionists, improving means not losing what one already has, i.e. it must be interpreted as resistance to removing anything from something that by definition already has and expresses quality.

\section{Assessments of the agents intervening in quality of employment}

The first striking aspect of the agents mentioned in the various discourses analysed is their diversity and their multiple relationships, which the groups point to with reference to their influence on the quality of employment. The actions of consumers or the local administration, employers, trade unions, family or trainers, etc. are judged and, at the same time, they judge the quality of existing employment. For example, for the union group, consumers are criticised as an external reason for justifying the low quality of employment, but these same consumers consciously or unconsciously, directly or indirectly, judge the quality of the service which affects employment conditions. It is the agents' actions which, to a certain degree, determine and influence the quality of employment product. These actions aim to sustain, produce or evaluate the quality of employment.

\section{Sustaining The QuALity of EMPLOYMENT}

Sometimes, the groups talk of agents who act in collusion with other agents or issues which directly or indirectly affect employment. This refers to a wide range of particular actions which contribute to maintaining a certain status quo. The agents may be in or outside the company, such as consumers, although they refer, above all, to those agents who are in contexts other than employment situations, or in a context of only examining and not acting as a result. In the case of the justice system it is obvious: for both trade unions and employers, and for different reasons, legislation that is not adhered to (or whose compliance goes against normal practices) is essentially an action that sustains low-quality employment.

\section{Producing The QUality of EMPLOYMenT}

In most of the agents mentioned by the groups, only some actions play a direct role in producing quality. All of the agents' influence is actually concentrated on these actions, although their role is very limited or specific on occasions, and focuses on aspects such as training, work and hiring. For the union group, it is mainly the trade unions and employers who perform actions aimed at producing 
quality, and for the latter, it is mainly the trainers, in general, and the workers who are responsible for the existence of quality jobs.

\section{EVALUATING THE QUALITY OF EMPLOYMENT}

Lastly, a series of reflexive actions aim to indicate or refer to the quality of employment for evaluation purposes. Both the trade unions and the employers perceive themselves as competent to perform this type of action, although other agents are mentioned, such as the various administrations or judges, who also decide and apply employment regulations to practices in companies. Even though it is the worker who the job is ultimately for, his or her assessments are not actually considered by the groups. There is no mention of the worker's actions to consider or recognise quality jobs. This silence could indicate that the worker is considered slightly incompetent for reasons that may be connected with his or her 'lack of judgement' or situation of dependence and immediacy when confronted with a job market that makes urgent demands with no time for any consultation or reflection. Nevertheless, and despite this symptomatic lack, these evaluations take on a commitment to notify, when not denouncing or complaining, by replacing or representing the voices of other agents involved (trade unions, administration).

Depending on the actions referred to, the groups judged agents as having good or bad quality. Those considered good include agents whose actions contribute variously to providing rather than removing quality in employment. In contrast, bad agents are those whose actions aim to remove rather than provide quality. Obviously, the same agent can be attributed with good and bad quality depending on his or her actions and the judges who evaluate them.

For example, for the union group, the Spanish employer is an agent whose actions mainly focus on producing quality of employment through hiring and working conditions. The difference lies in the fact that employers considered to be of quality do not stretch their egotism to the limit, 'to the point of not caring about people or the future of the company' This type of employer is also mentioned by the employer group, who they refer to the employer as seeking a 'quick buck': 'it's the quick-buck culture, there are employers who are insatiable.' The bad practices of an unscrupulous, speculative employer with no social conscience oppose the practices of a responsible quality employer whose actions are based on building up the company and looking after it.

Nevertheless, it is interesting to note that, for this union group, the quality of employment is affected by the bad quality of employers as well as by the quality of other agents whose actions sustain or justify the results of business decisions 
which 'remove quality'. These agents are, firstly, workers who betray their trade union role (employers' trade unionism) or simply, as mentioned above, those who are not interested in or do not have the judgement ability to be informed about the meaning of quality employment (immigrants, unqualified workers, young people looking for their first job, women who join the labour market for the first time, etc.).

The 'bad quality' of workers paradoxically not only impacts those whose work lacks quality, but also all other workers, whose actions to 'maintain quality' in their respective jobs or companies are thus limited due to inertia or contagion.

Along these lines, the citizens themselves are also considered bad quality agents for helping to maintain the deterioration of employment through their actions. By means of consuming with a lack of solidarity, or simply by supporting family members with jobs that lack quality, the actions of low-quality employers are reinforced, and this, along with the other agents sustaining bad quality, contributes to establishing a scenario without hope for quality agents (especially workers' trade unions), whose role is reduced to merely stating the resulting lack of quality.

In contrast, the employer group especially denounces workers' bad quality, although not as a reproach as the trade unions do (as it sustains the lack of quality). For them, workers are the main agent whose concerns do not necessarily include improving quality. In this regard, worker quality is revealed in the voluntary initiatives and actions they themselves put into practice to train and perform their jobs as best as possible. The quality of employment decreases as these actions are delegated or become insolvent. For this reason, the employer group talks about trainers as an especially necessary set of agents, but also as a group who, in turn, lack the required quality for their job of improving workers. Although employers think that training helps to infuse employment with quality, in actual fact its effects are not discernible, and it only affects the company as a burden (administrative paperwork, reorganisation of staff tasks, external audit of the company, etc.).

To sum up, both groups agree on the need to improve the agents involved in the quality of employment in Spain, although this improvement and its purpose are different for each group. For the trade unions, above all, agents need to be regenerated, and this also includes regaining the responsibilities they delegate, or avoid, as opposed to other agents who make an effort to maintain quality jobs. As mentioned earlier, this especially concerns the regeneration of unscrupulous employers and lazy and/or perverse workers (who betray workers' interests), as well as society as a whole, which allows this to happen and impassively watches 
the overall deterioration of the quality of employment. In the case of employers, this moral burden is omitted and replaced by the restoration which every salaried worker necessarily requires in market conditions - a restoration (called repair by the employer group to refer to training grants and subsidies for the unemployed, thus demonstrating employers' receptiveness to measures aimed at flexicurity) which implicitly highlights workers' bad quality and the burden this places on the employer in terms of training and suitability of jobs. In other words, if workers cannot find a quality job, this is not due to the fact that none are available or because employers refuse to devise them as such, but rather because this quality job has requirements which the agents involved (workers, trainers and administrations) fail to meet, or meet unsatisfactorily.

\section{Assessments of quality of employment contexts}

The contexts the groups refer to when speaking about the quality of employment are mainly financial and business, although specific references are made to the cultural and social context of employers or workers from Spain (or other countries) due to their involvement in the job market and employment relationships in the companies, business sector or economy in the country (or countries worldwide).

The analysis of quality of employment contexts involves job market referents which are internal and external, global and local, sectoral and intrasectoral, etc. With regard to time, these contexts are subject to the capitalist economic cycle of market expansion and contraction, prosperity and scarcity, 'boom years' and 'lean years', etc. When the opinions of both groups converge, they give rise to complex scenarios which can make it easier or more difficult to obtain quality of employment. For example, for both groups the current scenario of worldwide recession is not at all conducive to quality. For the trade unionist, this is because supply in the job market is shrinking, and because there is a significant reserve of manpower, which benefits the financial interests of companies. For employers, this is because competition in the market is intensifying, and rising productivity has become their major concern, instead of the quality of the work offered. As expected, since these situations or contexts are common, they have various interpretations and impacts.

As mentioned earlier, the trade unionists base their understanding of the quality of employment on an attribute with full value: only bad quality employment has no or not enough quality. The major concerns of the union discourse, therefore, focus on the decline in quality, and not on its growth, as expressed in the employer discourse. The two groups therefore have different reactions to apparently identical contexts. For the union group, the various 
contexts commented on are perceived as a threat, since they could involve a decrease or deterioration in the quality of employment: 'When we sit down at the bargaining table, we have all this, European regulations which transfer... some directives to be transferred and, at the same time, they put pressure on you and say: «Watch out for China! Ok?»»'(UG).

The clear risk of a reduction in the quality of employment is mentioned in global scenarios, in which foreign companies offer cheaper and more affordable labour, in which some business sectors are characterised by worse working conditions, in which there are intense migratory flows from economically depressed countries, etc. However, this risk is not considered inevitable in all scenarios. Especially in the case of unexpected and acquired contexts, such as the worldwide recession, a resigned attitude resulting from misfortune or a general change which affects everyone, but no one in particular, is quickly refocused and referred to other scenarios or previous contexts (in the near past) when the situation was not as equally unfavourable for all. This is the type of complaint made by the union group referring to a time when, for example, business owners lived off the fat of the land, but now tread cautiously, or when trade unions waive rights or claims in consideration of circumstances, but business owners do not respond in a similar fashion: 'Where is the money from that boom in the construction sector, for example (...) Where is it now?... when the sector needs a bit of propping up by the business owners... well what have we here (...) An extremely precarious situation'(UG).

In these cases, quality of employment contexts not only take into account connections between scenarios, but also the requirement for these scenarios to provide us with a better understanding of the quality of employment. For example, a comparison between the European and the Spanish situation highlights the difficulties and risks involved in maintaining standardised quality of employment based on regulations accepted by all the countries in the Union. For that reason, the union group does not accept comparisons between the quality of employment in Spain and other countries in Europe, which are far more advanced and aware of the subject ('We talk about flexibility, but it isn't the same' (UG)).

For trade unions, quality of employment has not deteriorated in the same way (and with the same intensity) in other countries as it has in Spain, which means that the standards or comparisons are actually more a problem of wellunderstood minimums rather than maximums or comparables to be attained. Therefore, an analysis of the above could lead to the conclusion that this is negative evaluation of the deterioration of quality rather than a positive one. This is the case of flexicurity, a feature of quality which cannot be evaluated by 
itself because it depends on the contextual and instrumental use permitted in each country, and a certain business culture: 'Spanish employers are not like Scandinavians, or the workers (...) In Spain it is going to be a disaster, because the Spanish employer is not as responsible as the Scandinavian one. And, therefore, naturally, if dismissal is easier for him, he is not going to make a tool out of it to turn his company into a competitive one with quality style and training' (UG).

For the employer group, the contexts of quality change are understood on the basis of the company's needs and the requirement to attain an acceptable level of quality for the circumstances and conditions at the time. In contrast to the union group, past scenarios are not revisited or linked to talk about the quality of employment. Instead, the situations or contexts they most discussed were in the most immediate present and future. As a result, their greatest problem originates in circumstances in which the quality of employment and the performance of business activities cannot happily coexist. In sectoral relations, especially with the public sector (but also in big companies) contexts and demarcations are more problematic because they serve as contextual referents of quality for the labour market as a whole: 'In our company those who leave go to work for the [public] administration. Whoever doesn't go to work for the administration is stupid' (EG). The strength of public employment in Spain becomes part of the scenario for employer discourse, in which the worker's quality is blocked or hindered by expectations of productivity or training which do not match the requirements of the market or Spanish business.

In short, contexts connected with free competition and the availability of trained and competitive human resources are linked to improved quality of employment in Spain. However, for the same reason, given the existing difficulties, specific scenarios of this type were not mentioned in the employers' group. Instead, they highlight employers' versatility in the multiplicity of contexts or adverse circumstances which directly or indirectly affect employment: 'An employer is a bit like water, if you don't give him a solution, he'll find the hole he can escape through, because that's why he's an employer. He takes risks, otherwise, with all due respect, he would be employed by a savings bank' (EG).

Therefore, the contexts in which the quality of employment becomes evident are especially realistic and supposedly threatening for the union group, since the specific job market situation in Spain has not demonstrated anything other than the tendency to decrease the quality of employment as long as political, social and financial conditions have allowed it to happen. In contrast, for employers, the quality of employment appears in forecasts, in which employment plays a key role in the company's development and survival, and adverse contexts 
full of difficulties require some acceptance and imagination to be overcome. Accordingly, quality employment is hidden or buried under contexts preventing it from emerging.

\section{Discursive strategies of social agents on the quality of employment}

The following is a brief interpretation of the interests and conflicts in the discourse on the quality of employment in Spain based on the discussions in each group and the issues they analysed.

Firstly, the subject of quality is a discursive production that is widely shared and used in various social, political and economic spheres. The particular characteristic of the discourse on the quality of employment is that it is a product, which, in turn, creates other products that can supposedly be evaluated from a quality perspective. The quality of the product or service provided is completely different from the quality of the employment capable of producing that product or service. It is obvious that the latter quality encompasses and says far more than the former. However, the important aspect is that it immediately connects and weakens both the product and employment, as if both terms actually meant the same thing and were interchangeable.

If quality (of employment or any other product) links the first stage, production, with the final stage, consumption, and makes them equal, it is because the discourse of quality is an add-on in the change from the capitalism of production to the capitalism of consumption, in which clientelism and user satisfaction is the return on the product and its (financial, political or social) sale obtained in the market.

The protection and extensive exploitation of national markets has shifted to the intensive exploitation and global opening of the world market, and in the case of employment and the job market, the transformation process has not been very different (Alonso, 2005, 2006). After the current neoliberal policies and the consolidation of a capitalist consumption-based economy, the deregulation of the job market has continued, and it has been customised to the point of altering union interests and strategies.

Having said this, the discourse on the quality of employment and on quality in general can be interpreted as an effect of the profound transformations that have taken place in Western capitalist economies. In this context, the traditional evaluation (and devaluation) of processes and resources changes to an evaluation of diverse products or outcomes, and they are evaluated by qualities or standards that reflect users' or consumers' acceptance and satisfaction. Evaluation becomes 
more distant and, therefore, there is more objectivity and neutrality in the discourse on quality. Reducing and simplifying the resources and processes to a final specific result, as well as making use of external competent arbitration, are the central issues on which the entire quality discourse is currently based.

With reference to employment in Spain, the quality discourse uncovers some relevant issues implicit in the previous paragraphs which are explored below (Table 1). Firstly, in the union discourse, it seems that the involvement of trade unions in employment management is diminishing and that, above all, they are powerless in a liberalising context which favours the employer class and new emerging markets (more competitive, fragmented and diversified, etc.). Any mention of the quality of employment in Spain focuses the discourse on the need to maintain (not lose) existing quality, which for trade unions, is also a difficult responsibility to assume in the current recession, especially with an employer culture that is not very receptive, or is even reluctant, to number the loss of good jobs among their main concerns.

The consequence of this initial approach is to be able to combine the protection of quality with its restoration. On the one hand, the union discourse understands that its role is to prevent existing quality from being further reduced (especially in those sectors most negatively affected by precariousness, low salaries, lack of protection, etc.). But, on the other hand, it also tries to regenerate employment where it has deteriorated. These objectives, completely absorbed within the union discourse, contradict a powerless union practice that is reduced to evaluating and certifying the (bad) quality of existing employment.

Trade unions come up against difficulties and contradictions in the process of bargaining for and creating quality employment in Spain. These include a reassessment of quality used for certifying purposes in terms of control of the conditions in which the jobs are carried out and adapting them to various standards of living by means of tests.

The discourse on the quality of employment distances trade unions from employment problems, yet it is also how they justify their powerlessness and lack of real resources to solve them. This 'exclusion' from employment management also involves blaming all the agents who directly or indirectly form part of the process leading to employment without quality, which largely justifies and explains the unions' loss of importance and influence on employers' actions. Employers, workers, administrations and citizens in general contribute in various ways to creating and sustaining low-quality employment in Spain, thus furthering the radius of action of the job market and of union claims in companies. 
This line of discourse, which is very close rhetorically to the conservation discourse, is taken with an awareness of the difficulties that trade unions currently face. The issue of informing the general public and making them responsible presupposes, on the one hand, linking union action with raising the awareness of all the agents who take part in the deterioration and/or overall restoration of the quality of employment and, at the same time, it describes a more complex and broad scenario demonstrating the effects of the various interactions that come into play in the improvement of employment.

On the other hand, it links the ideal of quality with the ideal of a quality job (a type or model of desirable but real quality employment) which tries to adapt (identify with) the supposed expectations of society as a whole and current legal requirements. Unlike the employer discourse, which refers to an ideal and unattainable type of quality, the union employment quality model tries to be consistent and realistic as it follows a specific referent connected with other social discourses (the acquisition of certain social rights, the standard of living attained by society, the defence of democratic principles, etc.).

As a whole, the quality of employment discourse is, for trade unions, a bridge or outlet for a supposedly union position that is blocked and/or burdened by market globalisation, the absence of regulating policies, difficulties for members, etc. At the same time, this outlet is the way for new discourses to connect and combine and, even though they are not, strictly speaking, union discourses, they can adapt and manage to play an important role in configuring a more sensitive unionism (more commercial or sellable with regard to quality) adjusted to the growing segmentation of the job market and employment relationships. This outlet and inlet is more pressing in Spain, as the Spanish situation is perceived as worse than in other countries or regions in the world. The quality discourse, therefore, contains the need for trade unions to adapt to the new prevailing reality (constant decrease in the quality of employment and a lack of a more convincing union response) and the new competences these should acquire to address more global actions consistent with the current job market.

The discourse of the group of union representatives can be interpreted as a last resort (a salutary lesson capable of promoting criticisms and the abandonment of sterile union positions), or as reassuring support for valuing the job market and employment from a more social and comprehensive perspective. In any event, this interpretation is very different from the one attributed to employers, whose discourse on quality starts by testing the central role they have in employment management and their particular opinions. 
If the union discourse is receptive and resents no longer being present in the management of quality employment (demonstrating an inability to deal with the various difficulties standing it its way), the Spanish employer discourse is at first unwilling and evasive, since the members of this group cannot deny the poor quality of employment and the direct references (especially in the union discourse) to their responsibility as the producer of low-quality jobs. In this respect, the mainly defensive purpose of the Spanish employers' discourse on quality is to:

- Deny their management role by disassociating themselves from the centre of action and/or the decisions that have implicitly or explicitly led to a situation of low-quality employment. 'I think there needs to be a campaign to make workers aware that, regardless of whether the company sends them on courses or not, training is their backpack, their curriculum vitae, their assets, not the employer's assets, but the worker's assets. (...) They are the ones who need to improve' (EG).

- Justify the refusal to raise the quality of employment at the same time as they relate that refusal to the importance of productivity in a financial and social context that is becoming increasingly competitive and globalised.

With reference to the first point, this quality discourse makes it possible for employers to replace and externalise their employment-producing (management) role by a certifying function on the basis of which they issue judgements on the quality required for a specific job. This evaluating role leads them to establish their discourse around the training required by workers to perform their jobs, and the adjustment of the job to the level of training workers in Spain have.

For employers, quality employment may be receiving the training the employer considers necessary to perform the job correctly. Employers have no objections to promoting quality employment and their aim is to do just that, as they perceive it as what productivity and adaptation to an increasingly competitive and demanding global market depend on.

According to the employers, the training quality of workers in Spain does not seem to meet the quality employment training standards required by the Spanish market, which highlights a deficiency employers do not see themselves as responsible for, except insofar as they accredit (objectively certify) the associated unsuitability and its effects (defects) on the country's and the company's economy.

Furthermore, the possibility of viewing employment management in terms of evaluation and matching it to workers' training allows employers to justify the prevailing situation and maintain it until the training deficiencies are overcome. Obviously, the reasons are related to the need to consolidate workers' training, 
but also to the assumption that training, and the fact that it has not been adapted to quality jobs, must be the stimulus to obtain such jobs. That is why the quality discourse of the employers directly attacks the public sector and governmentowned corporations, as a reaction to business activity that not only serves as an inappropriate benchmark for all workers, but which also ignores this stimulus and its benefits to incentivise productivity and, therefore, competition in the market.

Obviously, the symptomatic side of the quality discourse of employers is that it leads to a paradoxical acceptable situation of permanent dissatisfaction towards the existing quality of employment and the worker's level of training. In other words, for employers, quality can improve (grow) compared with an ideal referent which combines an indefinite number of necessary skills to do a good job, and which cannot be specified or established as definitive since they depend on the market and on improving productivity, which every economic company pursues. Furthermore, a worker's training quality cannot be nor should be close to the employers' ideal, because the latter would lose the guarantee of productivity stemming from deficient and/or inappropriate job market training.

Government-owned corporations, whose hiring process includes an objective test which must be passed to become a public sector employee, proves the possible association between a certain ideal quality of employment, and subsequent worker training and skills. The employer discourse sees the risk of non-productivity in this association, as once the worker finds a quality job, there is no longer any objective reason to continue encouraging him or her to improve.

Behind this apparent failing in workers' training and skills, promoted and sustained in turn by an unattainable ideal of quality, is the incentive that stimulates and supports the search for higher productivity and better employment, which leaves a trail of bad jobs and declining situations in its wake, and demonstrates, once and for all, the lack of competitiveness in the job market in Spain.

It is not contradictory, therefore, that the objective of the employer discourse on quality is to improve this quality whilst simultaneously alienating and destroying it. Given that the quality of employment is a demand for productivity in the employer discourse, the immediate consequence is that bad quality can be justified as a desirable starting point to achieve good jobs, and reform the workers and institutions regulating the market.

In short, the quality of employment discourse in Spain does not ignore its importance and its influence on the economy or on society as a whole. Based on this broadly shared viewpoint, the trade unions use the quality discourse as a means for examining and reconstructing their current role, extending their main 
concerns and paradigms from those which defend workers' interests to those which consolidate their criticism of a reprehensible Spanish employer class. For this reason, quality is expressed in the union discourse in exclusive terms of loss and not of gain, as it is in the employer discourse, which is used by employers for mainly production purposes to maintain their privileged position in the management of employment and to improve the image they portray to society.

Table 1 Discursive features of the quality of employment in Spain

\begin{tabular}{|l|l|}
\hline TRADE UNIONS & EMPLOYERS \\
\hline Blaming / conservation discourse & Defensive / economic discourse \\
\hline $\begin{array}{l}\text { Aimed at denouncing and claiming the lost } \\
\text { quality of employment }\end{array}$ & $\begin{array}{l}\text { Aimed at justifying the situation of the lack } \\
\text { of quality of employment and promoting its } \\
\text { improvement }\end{array}$ \\
\hline $\begin{array}{l}\text { Realistic discourse: centred on an ideal of } \\
\text { employment quality }\end{array}$ & $\begin{array}{l}\text { Fictitious discourse: centred on an ideal quality } \\
\text { of employment }\end{array}$ \\
\hline $\begin{array}{l}\text { With universal scope, referring to all of } \\
\text { society and rights attained }\end{array}$ & $\begin{array}{l}\text { With local scope, referring to the company itself } \\
\text { and the rules of the free market }\end{array}$ \\
\hline
\end{tabular}

\section{Conclusion}

The use of the term quality to refer to employment has placed a series of new ideas and very important transformations on the table. Employment has become yet another market product whose value is determined by demand - by those who seek and consume it. In other words, the job market is analysed from a strict clientelist viewpoint. Furthermore, adopting the quality form to address the job market and its management has profound political, social and economic implications. This is quite a change, which originates with the post-Fordist model and the emergence of quality.

For employers, the clientelist stance means the entire job market is potentially a customer of the jobs offered, and their aim is to mobilise the workforce as much as possible and regardless of the market's limitations and structural determinants (training, skills, availability, etc.). Market expansion and intensification are two objectives employers meet using quality as a mechanism for job market segmentation and diversification, and by suitably tailoring the adjustment between supply and demand: the various qualities of employment correspond to different levels of worker training.

Trade unions respond to this extensive and intensive exploitation of the markets by rejecting the diversification and growing segmentation of the quality of employment, because they understand that this deteriorates jobs in general. 
They become replacements for or imitations of the employment product in absolute terms. Consequently, the union discourse aims to restore lost jobs with the use of quality, trying to cancel out the growing deterioration and reduction of the product. It is therefore not surprising that the union discourse is linked to the conservation discourse, not only because they share common ground in seeking to return to the origin (natural state of affairs), to the original jobs without any cutbacks, but also because the quality of employment affects workers, as well as other product or service consumers. A low-quality job results in low-quality service, and the general public, present in both the conservation and union discourses, has become involved in an attempt to make society take responsibility.

The claim for a job with rights (decent work ${ }^{5}$ ) is the idea of employment which trade unions are trying to revive. A decent job that can be lived on, i.e. that satisfies the worker's socially conditioned requirements which are met by the need for a job with certain quality requisites or dimensions. As far as employers are concerned, they will include these dimensions to suitably stimulate the demand for jobs and, as with all products, this demand needs to be kept permanently unmet.

In the union discourse, stability, salary, work and family life balance, training and health are the most relevant dimensions in assessing the quality of employment. Attaining a positive rating in all of them is only possible because there is a framework of rights, which presupposes an implicit sixth dimension of quality, which is employment with rights. These dimensions cannot be neglected, and all of them must occur simultaneously in order for a job to be considered quality employment. A stable job that does not pay enough to live on, because another job is needed, does not make it possible to be independent or to start a family and is therefore not a quality job. A good salary, but only for a certain period of time, is not enough to live on either. If a worker has all of the above, but no work and family life balance, and he or she is forced to choose between his or her professional and personal life, or if no training is provided on the job to ensure the required stability, salary, etc., then it is not a quality job either.

In contrast to the quality referred to by trade unions, employers talk about qualities. This is because, for the former, the dimensions allow no room for reductions, since their concept of quality is absolute (there is or there is not

5 There has been a great deal of discussion about how close the strategic plan of decent work of the ILO (1999) is to the quality in employment of the EEA (EC, 2001, COM, 2002 and 2003). Some analyses have purported to see some similarity between the two programmes (Rubery and Grimshaw, 2001; Barbier and Schylla, 2004). For others, however, there is a huge gap between the two approaches (Prieto et alii, 2009). In this article, we maintain that the union approach to quality would be close to the idea of decent work, and, therefore, far removed from the employer and European Commission approach. 
quality), whilst for the employers, the dimensions allow for gradients. There is security, but there are many securities, different salaries, training levels, etc.

For employers, the system of dimensions which quality represents does not match the system of dimensions which decent work involves for trade unions, because this would mean that the motivation the employer class gives to the various qualities of employment would disappear. Nevertheless, the fact that they do not match does not mean that there are no connections between them. As mentioned above, the employers' system of quality dimensions takes the union system as a reference, because in keeping with the clientelist logic, the product offered must meet the expectations of potential demand.

Of all the dimensions of a quality job, training sparks a special interest in employers because it allows them to structure and justify the segmentation of qualities of employment and the associated allocation of available jobs. This route also dilutes any conflict between employers and workers, as everyone can have a job, but not of the same quality. However, regardless of the level of training, trade unions understand that workers should be able to restore the decency and absolutes (no reductions or gradients) of their job, i.e. have decent work. Nevertheless, this job runs the risk of being repossessed by the employer discourse, if it has not already occurred, as another side to the increasing segmentation of the qualities the market displays: a high-quality employment product unattainable for the vast majority of the market.

\section{References}

Alonso, L. E. (1998). La mirada cualitativa en Sociología. Fundamentos, Madrid. Alonso, L.E. (2005). La era del consumo. Madrid, Siglo XXI.

Alonso, L. E. (2006) «A post-fordist consumption norm? Social fragmentation, individualization and new inequalities», Alonso, L. E. and Martínez, M. (Ed) Employment Relations in a Changing Society: assessing the post-fordist paradigm. Bakingstoke Palgrave Macmillan, pp153-168.

Arnal, M.; Prieto, C. and Caprile, M. 'Quality of employment in Spain: analysis of the discourse of social agents', International Journal of Society Systems Science (in press).

Barbier, J.C. and Schylla, N.S. (2004). La Stratégie européenne pour l'emploi: genèse, coordination commuautaire et diversité nationale, Centre d'Etudes de l'Emploi, Rapport recherche.

Callejo, J. (2001). El grupo de discusión: introducción a una práctica de investigación. Ariel, Barcelona. 
Canales, M. (2006). «El Grupo de Discusión y el Grupo Focal» en Canales, M. (Ed) Metodología de investigación social. Santiago de Chile LOM, pp. 265-287.

Clark, A. E. (2005). «Your money or your lifeः changing job quality in OECD Countries», British Journal of Industrial Relations, no 43, pp. 377-400.

Conde, F. (2009). Análisis sociológico del sistema de discursos. Colección Cuadernos de Metodología, no 43, CIS, Madrid.

Davoine, L*; Erhel, C. and Guergoat-Lariviere, M. (2008). «Monitoring quality in work: European Employment strategy indicators and beyond», International Labour Review 147, no 2-3, pp.163-198.

European Commission (2001). Políticas sociales y de empleo. Un marco para invertir en calidad, EC (2001) 313 final.

European Commission (2002). Balance de cinco años de estrategia europea de empleo. Comunicación al Consejo y al Parlamento, COM (2002) 0416 final.

European Commission (2003). Mejora de la calidad del empleo: examen de los progresos recientes. Bruselas, 26.11.2003. COM(2003) 728 final.

Gallie, D. (2007).Employment Regimes and the Quality at Work, Oxford, Oxford University Press.

Green, F. (2006). Demanding Work. The Paradox of Job Quality in the Affluent Economy. Princeton and Oxford: Princeton University Press.

Gutiérrez Brito, J. (2008). Dinámica del grupo de discusión. Colección Cuadernos de Metodología, no 41, CIS, Madrid.

International Labour Organization (ILO) (1999). Report of the DirectorGeneral: Decent work. International Labour Conference, $87^{\text {th }}$ Session, Geneva.

Kalleberg, A.L.; Reskin, B.F. and Hudson, K. (2000). 'Bad jobs in America: standard and nonstandard employment relations and job quality in the United States', American Sociological Review, Vol. 65, No. 2, pp.256-278.

Prieto, C. (coord.), Arnal, M., Caprile, M. and Potrony, J. (2009). La calidad del Empleo en España: una aproximación teórica y empírica. Ministerio de Trabajo, Seguridad Social e Inmigración, Colección Economía y Sociología del Trabajo no 84, Madrid.

Rubery, J. and Grimsahw, D. (2001). «Las nuevas tecnologías y el problema de la calidad», Revista Internacional del Trabajo, 120(2): 155-190.

Rusell,J.P.(Dir*) (2000). The Quality Audit Handbook. Principles, Implementation and Use. Wisconsin, American Society for Quality.

Sengupta, S., et alii (2009). "The good, the bad, and the ordinary. Work identities in good and bad jobs in the United Kingdom», Work and Occupations February, 2009 Vol. 36, no 1 pp. 26-55. 